\title{
Understanding Resident Intention and Behavior toward Water Conservation Initiative in the Upstream of West Java, Indonesia
}

Prasetyo Nugroho ${ }^{1 *}$, Apriliyanti Dwi Rahayu ${ }^{2}$, Rany Juliani ${ }^{3}$, Indarto ${ }^{2}$, Alfian Dwi Cahyo ${ }^{2}$, Nida Ankhoviyya $^{2}$, Edwin Gumilar ${ }^{1}$, Denni Susanto ${ }^{1}$, Adi Nugroho ${ }^{1}$

${ }^{1}$ Department of Bioresources Technology and Veterinary, Vocational College of Universitas Gadjah Mada. Yogyakarta, 55281, Indonesia

2 Yayasan Javlec Indonesia. Sleman, 55581, Yogyakarta, Indonesia

${ }^{3}$ PT. Tirta Investama Plant Subang. Bojongloa, Subang, 41283, West Java, Indonesia

* Corresponding Author. E-mail address: prasetyonugroho@ugm.ac.id

\section{ARTICLE HISTORY:}

Received: 5 July 2021

Peer review completed: 8 November 2021 Received in revised form: 16 November 2021 Accepted: 30 November 2021

\section{KEYWORDS:}

\section{Attitude}

Cipunagara watershed

Theory of planned behavior

Subang
(C) 2022 The Author(s). Published by Department of Forestry, Faculty of Agriculture, University of Lampung in collaboration with Indonesia Network for Agroforestry Education (INAFE). This is an open access article under the CC BY-NC license:

https://creativecommons.org/licenses/by$\mathrm{nc} / 4.0 \%$.

\begin{abstract}
Upstream areas have long been targeted as the priority of water conservation initiatives. While earlier studies often considered underlying socio-psychological factors determining residents' intention and behaviors in water conservation, studies that focused on the resident's intention and behavior in upstream areas, where water is abundant, remain underexplored. The current study used socio-psychological constructs of the theory of planned behavior (TPB), i.e., subjective norm, attitudes toward behavior, and perceived behavioral control, to analyze the determinants of water conservation intention and behavior in two villages upstream of West Java (i.e., Cibeusi and Sanca villages), Indonesia. A total of 200 usable questionnaires were retrieved. Structural equation modeling was used to determine the linkages and strength of relationships among constructs. There was evidence that residents perceived behavioral control exerted the most significant influence on residents' water conservation intention and behavior. Moreover, perceived behavioral control was an effective mediator of the linkage between attitude and residents' intention and behavior. The findings confirmed the suitability of TPB in explaining interrelationships among determinant factors that explain residents' intention and behavior, albeit with different mechanisms and effects. The study implied that increasing awareness of the value of water conservation would significantly affect residents' attitudes, which subsequently increased their willingness to perform water conservation efforts.
\end{abstract}

\section{Introduction}

Water availability and conservation have become one of the most contentious issues facing global society (Dinar et al. 2019; Lee et al. 2020; Taherzadeh et al. 2021). The upstream areas, the zero to the first-order watershed, are fragile ecosystems and are suspected as the most sensitive parts of landscapes (Křeček and Haigh 2019; Li et al. 2021). While providing essential ecosystem services (e.g., groundwater recharge, mitigating floods, drought occurrences) (Nugroho et al. 2013; Suryatmojo 2015; Zheng et al. 2019), upstream areas deal with the most significant challenges on natural resources depletion, climatic and socio-economic changes (Booij et al. 2019; Di Matteo et al. 2017; Marhaento et al. 2018). At this point, there is beyond doubt that changes in 
upstream areas may have adverse downstream impacts on erosion, water supply, sediment transport, and water quality (Moragoda and Cohen 2020; Valentin et al. 2008). Therefore, they pose the most significant challenges for resource managers and policymakers in managing upstream areas to ensure the sustainability of critical environmental services they serve (Křeček and Haigh 2019).

However, managing upstream areas is a complex task that involves the integration of numerous scientific judgments. Biophysical approaches are prominent, and on the other hand, scholars argue that strategies to deal with water scarcity and its conservation are contingent upon the social dimension approach (Chaudhary et al. 2017; Floress et al. 2017; Kumar et al. 2020; Valizadeh et al. 2020). These include understanding residents' opinions and psychological processes toward water conservation behavior. Specifically, since water conservation practices at the individual level are substantial (Russell and Knoeri 2020; Tama et al. 2021; Warner 2021), understanding factors that determine positive water conservation intentions and behaviors may provide reliable information for resource management decision making. Indeed, earlier studies have been dedicated to explaining precedents of individuals' intentions and behaviors in saving water (Maleksaeidi and Keshavarz 2019; Perren and Yang 2015; Savari and Gharechaee 2020; Shahangian et al. 2021; Valizadeh et al. 2020; Yazdanpanah et al. 2014, 2016). However, these studies were primarily conducted in the area which endures water scarcity and drought. The existing literature gives vague answers on the upstream regions where water is usually abundant. More importantly, how residents' attitudes, social pressure, and perceived control over conservation activities in the upstream areas influence their water conservation intention and behavior have not been studied.

Therefore, to explain the plausible linkages and empirical test the plausible interactions among determinants of residents' water conservation intention and behavior in the upstream areas, the study focuses on two villages (i.e., Cibeusi and Sanca) at the upstream of West Java, Indonesia. Those villages had total annual rainfall of 5,297 in 2018 (BPS Kabupaten Subang 2019a). The current study aimed to investigate the determinants of residents' water conservation intention and behavior. To explain that, the study employs the theory of planned behavior (TPB) proposed by Ajzen (1991). TPB has been extensively used in conservation studies, particularly research focused on psychosocial and behavioral mechanisms (Perren and Yang 2015; Russell and Knoeri 2020; Shahangian et al. 2021; Valizadeh et al. 2020). The findings may add fundamental knowledge for policy measures to improve water conservation management and generate more conservation behavior.

\section{Materials and Methods}

\subsection{Conceptual Framework and Research Hypothesis}

The Theory of Planned Behavior (TPB) is a notable socio-psychological model to elucidate variance in purposeful behavior, proposed by Ajzen (1991). TPB argues that an individual's actual behavior (B) is directly governed by behavioral intention (BI). Subsequently, BI is simultaneously influenced by the subjective norm (SN), attitude (ATB), and perceived behavioral control (PBC) toward the behavior. The research defined behavior as residents' involvement in water conservation programs in their villages. Accordingly, a resident's BI is described as their willingness to engage in water conservation initiatives in their village. $\mathrm{SN}$ is demonstrated as social 
pressure from external sources to govern an individual's intention and behavior. At the same time, ATB reflects the degree to which a person favors the BI water of conservation initiatives. In addition, $\mathrm{PBC}$ is defined as the person's perceived capability or self-efficacy to engage in a specific behavior. Theoretically, an individual's intentions and behavior are more robust when those SN, ATB, and PBC are in a more favorable situation (Ajzen 1991; Yazdanpanah et al. 2014). Following those arguments, the research proposed the following hypotheses (Fig. 1).

H1. Attitude toward behavior (ATB) directly and positively affects behavioral intention (BI),

H2. Subjective norm (SN) directly and positively affects behavioral intention (BI),

H3. Perceived behavioral control (PBC) directly and positively affects behavioral intention (BI),

H4. Perceived behavioral control (PBC) directly and positively affects behavior (B),

H5. Behavioral intention (BI) directly and positively affects behavior (B).

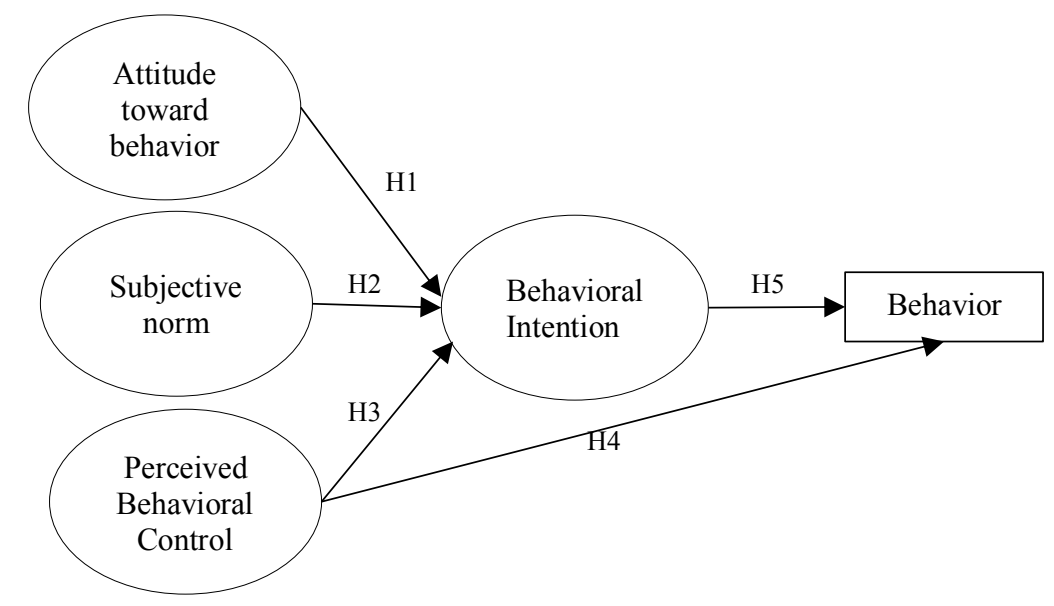

Fig. 1. The conceptual model of the study.

\subsection{Study Site}

Cibeusi and Sanca villages are located upstream of the Cipunagara watershed, as shown in Fig. 2. Administratively, the villages are located in Subang Regency, West Java Province, Indonesia. Cibeusi and Sanca villages are inhabited by 2,864 and 4,727 residents, respectively. Both Cibeusi and Sanca receive relatively abundant rainfall throughout the year since they are located in the upstream area (BPS Kabupaten Subang 2019). In total, the annual rainfall in those villages was 5,297 mm in 2018 (BPS Kabupaten Subang 2019). In the context of watershed management, earlier studies have demonstrated that the Cipunagara watershed has experienced landcover changes leading to soil erosion, water pollution, sediment transport, and water arrangement disturbances (Fitriyana et al. 2020; Juwana and Nugroho 2020; Nur et al. 2020). For instance, Fitriyana et al. (2020) elucidated that the highest sediment transported through the river in the Cipunagara watershed was more than 1 million tons. $\mathrm{ha}^{-1}$. year ${ }^{-1}$. Moreover, Juwana and Nugroho (2020) indicated that in the middle part of the Cipunagara watershed, for existing Biological Oxygen Demand (BOD) and Chemical Oxygen Demand (COD) pollutants were 1.67 tonnes.day ${ }^{-1}$ and 5.06 tonne. ha ${ }^{-1}$, respectively. Given these circumstances, the upstream areas (e.g., Cibeusi and Sanca villages) play a strategic role in conserving water (Marhaento et al. 2018; Nugroho et al. 2013; Suryatmojo 2015). 
Those two villages were explicitly selected for the study because they have long received water conservation programs (i.e., forest rehabilitation, infiltration wells, and community development) from the local government and private sectors (Javlec 2021; Pemerintah Daerah Jawa Barat 2019). These include implementing soil and water conservation techniques (i.e., infiltration wells, ditches) and community empowerment in environmentally based landscape management. For instance, 1,210 trees have been planted, 8 vertical drainages and 90 ditches have been deployed in 2019 (Javlec 2019). Moreover, Cibeusi and Sanca, which cover a 363-ha and 634-ha area, are acknowledged as crop producers of rice, carrot, and shallot in West Java. Accordingly, most residents work in farming-related activities and laborers, while a small portion of them work as civil servants, staff, and entrepreneurs (BPS Kabupaten Subang 2019).

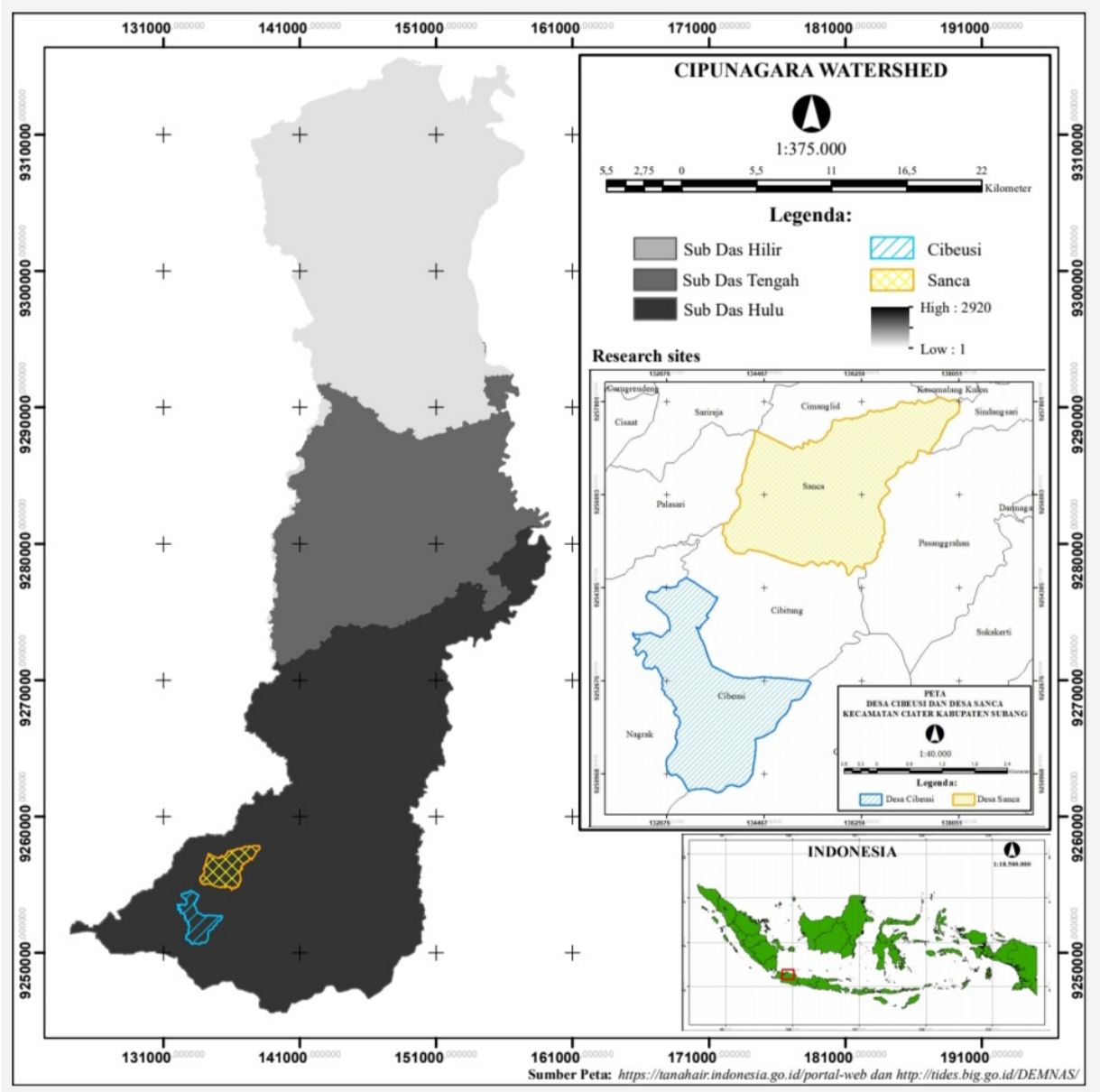

Fig. 2. Research sites and map of Cipunagara watershed.

\subsection{Questionnaire Development}

We developed a structured questionnaire survey to describe the determinants of residents' intentions, behavior toward water conservation, and demographic characteristics. The current study considers the Theory of Planned Behavior (TPB) (Ajzen 1991) as the theoretical model. The questionnaire was divided into two major sections. The first section comprises five latent variables of the TPB framework (Ajzen 1991). Moreover, the observed variables were adopted from earlier research, including the subjective norm (SN), attitudes toward behavior (ATB), perceived behavioral control (PBC), behavioral intention (I), and behavior (B) (Ajzen 2002; Chaudhary et al. 2017; Chien et al. 2012; Mihanyar et al. 2016; Shahangian et al. 2021; Warner et al. 2018; Warner 2021; Yazdanpanah et al. 2014). In total, the initial structured questionnaire comprised 20 
question items. Respondent's statements were set on a 5-point Likert scale, with 1 referring to "strongly disagree" and 5 referring to "strongly agree". The second part of the questionnaire asked gender, age, formal education attainment, and personal monthly income. These questions were utilized to describe the characteristics of the respondents.

\subsection{Survey Procedures}

The study employed a non-probability purposive sampling procedure to determine the sampled villages. Guo and Hussey (2004) explained that the technique allows the scholar to select a sample based on specific issues and specific judgments. More importantly, this method is robust in examining the theoretical framework and locating a broader population's phenomena (Etikan et al. 2016; Rivera 2019). Among the villages situated upstream of the Cipunagara watershed, Cibeusi and Sanca were chosen as a case study. Data were collected in October 2020.

We hired and trained three interviewers with a forestry and social science background to encourage residents' participation in the survey, execute interviews, and manage questionnaire data. On-site interviews were performed face-to-face in the field and door-to-door in the settlement areas of the targeted villages. The total number of residents in the two targeted villages was 7,591 (BPS Kabupaten Subang 2019). Therefore, randomization and testing the entire population are practically almost impossible due to limited resources. Due to the budget and time limitations, this study utilized the convenience sampling method to intercept respondents based on their accessibility and willingness to engage in the questionnaire survey (Etikan et al. 2016). Using a priori method (Soper 2021), we generated the minimum sample size to determine the anticipated effect size and desired statistical power level of analysis (Christopher Westland 2010; Memon et al. 2020). Accordingly, the minimum sample size to detect effect and model structure was 150 respondents. The intercepted locals were first asked whether they were occupants and were aged $>18$ years old. Next, they were informed about the study's purpose and asked their willingness to participate in the survey. Finally, they were requested to answer the question items on site.

\subsection{Data Analysis}

Residents' demographic characteristics were analyzed descriptively using RStudio (Team 2015). Moreover, this study performed structural equation modeling (SEM) analysis. SEM has been extensively used to investigate causal-effect linkages among variable interests in behavioral research (Tarka 2017). It allows assessing measurement error, estimating latent variables via measured variables, and model testing where a model structure can be compelled and examined to fit the observed data simultaneously. The SEM involves subsequent confirmatory factor analysis (CFA) and path analysis procedures (Weston and Gore 2006). Initially, the proposed theoretical model (TM) was assessed using CFA to examine the effectiveness of the measurement model. The measurement model represents a CFA used to justify and explore the relationship between latent and observed variables (Bagozzi and Yi 1988; Hair et al. 1998). We also assessed the global model fit indices, composite reliability (Ahmad et al. 2016; Bagozzi and Yi 1988), and convergent validity (Ahmad et al. 2016; Bagozzi and Yi 1988) latent variables to ascertain the quality of the measurement model. Next, the suspected latent variables with unsatisfactory fit index were reassigned by deleting its observed variables with the lowest loading factor value (Ahmad et al. 2016; Fuchs and Diamantopoulos 2009; Gerbing 1988; Iacobucci 2009). The study considered gunning fog index (GFI) (Schumacker and Lomax 2004), comparative fit index (CFI) (Bentler, 
1990), normed fit index (NFI) (Bentler and Bonett 1980; Schumacker and Lomax 2004), parsimonious index (chi-square/df) (Kline 2011; Schumacker and Lomax 2004) as the model fit index. Hence, the procedure lessens the number of observed variables in each designated latent variable. Third, path analysis was run to estimate all path relationships among latent and observed variables using the maximum likelihood approach. Next, the directions and significant path relationships among latent variables were determined by simultaneously verifying all proposed hypotheses. Moreover, the validity of the generated model was evaluated by examining the average variance extracted (AVE) and composite reliability (CR) (Hair et al. 1998; Weston and Gore 2006). In the end, the best structural model was further evaluated by comparing chi-square/df and Akaike Information Criterion (AIC) values of the competing models (CMs) with the proposed theoretical model (TM). The measurement models and structural model fit indices were analyzed utilizing the lavaan package (Rosseel 2012) in RStudio ver. 1.1.4.6.3 (Team 2015).

\section{Results and Discussion}

\subsection{General Results}

In total, 200 usable questionnaires were obtained. Of the respondents, $64.5 \%$ were male, and most were between 20 - 50 years old (75\%). Most of the respondents had completed high school (33.5\%), 27.5\% had graduated junior high school, and 4.0\% were illiterate. The majority, $86.0 \%$, of the respondents had earned personal monthly income of < IDR 2,500,000 (USD 176.3), and only $14 \%$ gained $>$ IDR 2,500,000 (USD 176.3) (USD 1 is equal to IDR 14,176.05 as of May 11, 2021).

The original questionnaire was composed of 6 latent variables and 20 observed variables. The overall mean values of ATB, SN, PBC, BI, PR, and B were 4.25, 3.76, 3.73, 3.88, 4.00, and 3.89 , respectively. In addition, the standard deviations of ATB, SN, PBC, BI, PR, and B were 0.60, $0.65,0.69,0.58,0.84$, and 0.67, respectively. The value of Cronbach's alpha $(\alpha)$ of all latent variables was $>0.5$, demonstrating a high level of reliability (Taber 2018). Table 1 demonstrates the overall value of latent variables.

Table 1. The overall value of research latent variables

\begin{tabular}{lccc}
\hline \multirow{2}{*}{ Latent variables } & \multicolumn{3}{c}{ Overall value } \\
\cline { 2 - 4 } & Mean & SD & Cronbach's alpha \\
\hline Attitude toward behavior $(n=5)$ & 4.25 & 0.60 & 0.79 \\
Subjective norm $(n=3)$ & 3.76 & 0.65 & 0.87 \\
Perceived behavioral control $(n=4)$ & 3.73 & 0.69 & 0.79 \\
Behavioral intention $(n=4)$ & 3.88 & 0.58 & 0.73 \\
Behavior $(n=1)$ & 3.89 & 0.67 & \\
\hline
\end{tabular}

Note: $\mathrm{SD}=$ standard deviation, $n=$ number of questions.

\subsection{Measurement Model}

The measurement model of this study involved six latent variables. However, the actual results of the CFA analysis were unsuccessful in providing acceptable fit model indices. Consequently, we deleted nine observed variables (i.e., three items for ATB, two items for BI, 1 item for PR, and three items for BI) to establish an acceptable measurement model. The parsimonious fit index for the analysis was 3.34, and the allowable value is $<5$ (Schumacker and 
Lomax 2004). The subsequent model fit indices included gunning fog index of 0.931, a comparative fit index of 0.943 , normed fit index of 0.921 . Those generating model fit indices represent that the proposed measurement model well-fitted to the observed data. Moreover, the convergent validity (CR) of all latent variables was above 0.7 , the average value extracted (AVE) was $>0.5$, and these eventually demonstrated a high level of internal consistency of the generated model (Ahmad et al. 2016; Bagozzi and Yi 1988). Table 2 presents the loading factor, average variance extracted (AVE), and composite reliability (CR) from the designated measurement model. The loading factor represents the estimated direction and strength of the correlation coefficient between the measured and latent variables. In SEM, 0.7 or higher loading factor demonstrates that the factor extracts sufficient variance from the designated latent variable (Taber 2018).

Table 2. Loading factor, CR, and AVE from the measurement model

\begin{tabular}{|c|c|c|c|}
\hline Variable & $\begin{array}{l}\text { Loading } \\
\text { Factor }\end{array}$ & $\mathbf{C R}$ & AVE \\
\hline \multicolumn{4}{|l|}{ Attitude Toward Behavior (ATB) } \\
\hline I think that engaging in water conservation is wise & 0.956 & 0.78 & 0.64 \\
\hline I think that engaging in water conservation is favorable & 0.792 & & \\
\hline \multicolumn{4}{|l|}{ Subjective Norm (SN) } \\
\hline $\begin{array}{l}\text { Most people who are important to me would think I should engage in water } \\
\text { conservation activities in this village }\end{array}$ & 0.793 & 0.88 & 0.71 \\
\hline $\begin{array}{l}\text { Most people who are essential to me recommend engaging in water conservation } \\
\text { activities in this village }\end{array}$ & 0.907 & & \\
\hline $\begin{array}{l}\text { Most people who are important to me would approve me to engage in water } \\
\text { conservation activities in this village }\end{array}$ & 0.827 & & \\
\hline \multicolumn{4}{|l|}{ Perceived Behavioral Control (PBC) } \\
\hline $\begin{array}{l}\text { It is primarily up to me whether I engage in water conservation activities in this } \\
\text { village }\end{array}$ & 0.792 & 0.80 & 0.67 \\
\hline $\begin{array}{l}\text { Nothing prevented me from engaging in water conservation activities in this } \\
\text { village }\end{array}$ & 0.843 & & \\
\hline \multicolumn{4}{|l|}{ Behavioral Intention (BI) } \\
\hline I intend to engage in water conservation activities in this village & 1 & & \\
\hline \multicolumn{4}{|l|}{ Behavior (B) } \\
\hline I Involved in water conservation efforts in this village & 1 & & \\
\hline
\end{tabular}

\subsection{Structural Model}

The research assessed the determinants of residents' intention and behavior toward water conservation efforts in the upstream area. Interestingly, instead of attitude and subjective norm, the research findings implied that residents perceived behavioral control is the significant determinant of their intention and actual water conservation behavior. Fig. 3 shows the path diagram for structural relationships among latent constructs and their impacts.

The SEM analysis revealed that behavioral intention (BI) directly, positively, and significantly affected behavior (B) $(\beta=0.38, p<0.001)$, thus H5 was accepted. The finding was consistent with earlier studies (Shahangian et al. 2021; Yazdanpanah et al. 2014). The results also indicated that if residents hold a stronger intention to engage in water conservation initiatives, they are likely more involved in water conservation activities in their village. 

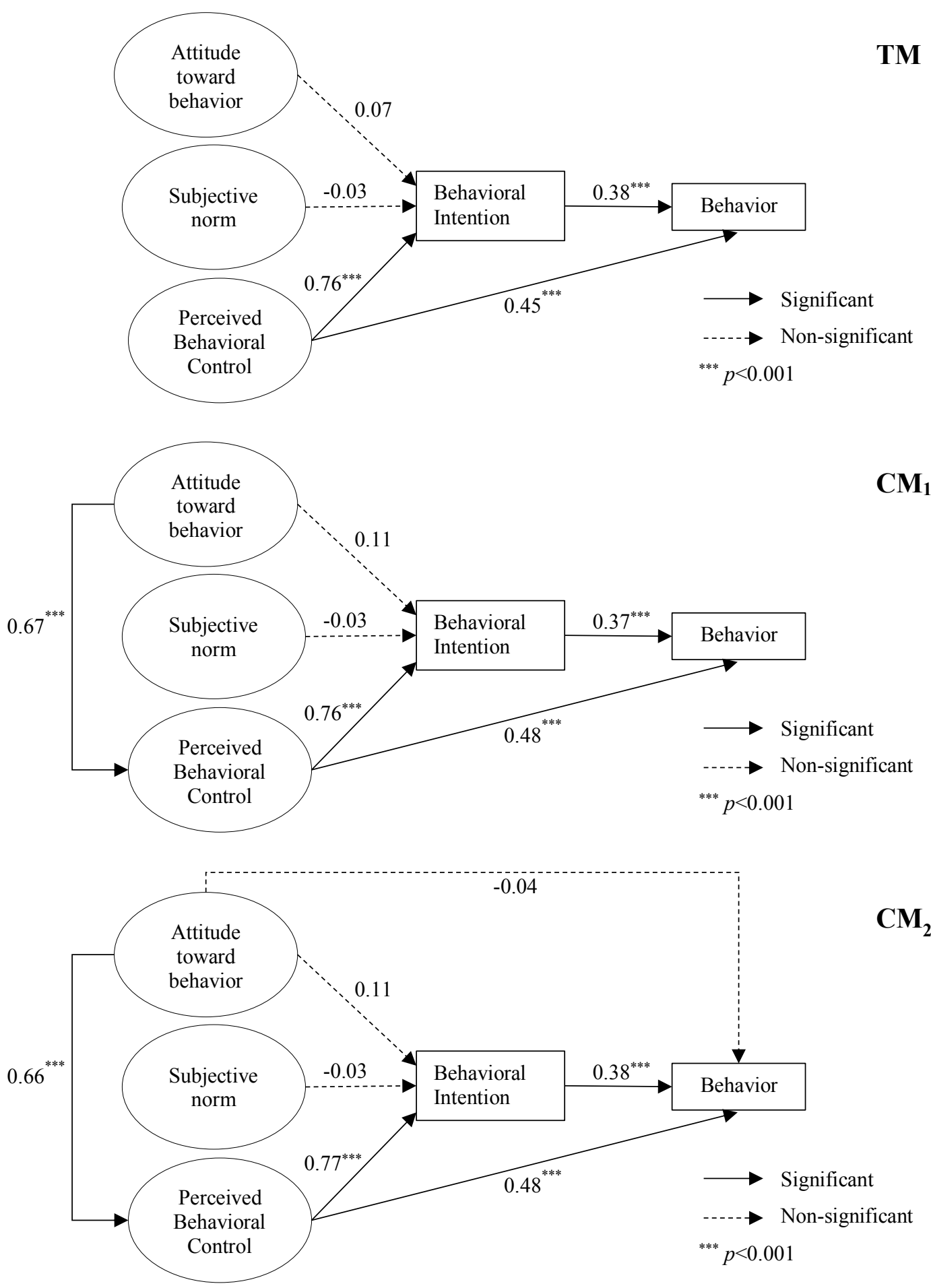

Fig. 3. Structural model of resident intention and behavior toward water conservation (TM= theoretical model, $\mathrm{CM}=$ competing model).

Moreover, residents' intentions and behavior in water conservation were strongly and significantly governed by their perceived behavioral control. The PBC directly, positively, and significantly affected BI $(\beta=0.76, p<0.001)$. It also directly, positively, and significantly affected behavior $(\beta=0.45, p<0.001)$, thus $\mathrm{H}_{3}$ and $\mathrm{H}_{4}$ were accepted. We also found that the ATB directly, positively, and non-significantly affected behavioral intention $(\beta=0.07, p>0.05)$. Thus, $\mathrm{H}_{1}$ was accepted. The SN directly, negatively, and non-significantly affected $\mathrm{BI}(\beta=-0.03, p>0.05)$, therefore $\mathrm{H}_{2}$ was rejected. Existing literature indicates that the subjective norm is an infirm 
determinant of an individual's intention (Armitage and Conner 2001; Shahangian et al. 2021). Most importantly, the research findings demonstrated that subjective norms (i.e., social pressure) and attitudes toward water conservation were not significant driving forces of residents' intention to engage in water conservation. Our findings also contradicted those who researched the area with vulnerability to natural resources problems (Maleksaeidi and Keshavarz 2019; Shahangian et al. 2021; Yazdanpanah et al. 2014, 2016). For instance, Shahangian et al. (2021) asserted that Iran's severe water crisis led the residents to hold higher water efficiency intentions and behavior agreements. Given these circumstances, we speculated that these contradictory findings might be related to residents' level of exposure to water problems, i.e., water shortage and water pollution. The upstream of the Cipunagara watershed is well known as an area with abundant rainfall throughout the year (BPS Kabupaten Subang 2019); thus, the water shortage has remained overlooked. Consequently, residents' water conservation intention and behavior were explicitly governed by their perceived behavioral control. Those who have stronger self-efficacy, perceived belief, and controllability over adopting water conservation behavior in their village are more anxious to engage and adopt such water conservation behaviors. Therefore, promoting residents' confidence in water conservation practices through extensive training and empowerment programs to overcome perceived barriers may nurture residents' behavior in conserving water.

The $\mathrm{CM}_{1}$ was the best model for the current study (Table 3). Interestingly, we found that attitude toward behavior directly, positively, and significantly affected perceived behavioral control $(\beta=0.66, p<0.001)$ and indirectly, positively, and significantly affected intention and water conservation behavior. Following the SEM results of $\mathrm{CM}_{1}$, the influence of residents' attitudes on their intention and water conservation behavior was fully mediated by perceived behavioral control. It implies that the residents who perceived water conservation as wise and favorable actions had more confidence and ability in conserving water in their village, which eventually bolsters their intention and actual water conservation behaviors.

Table 3. Fit indices for competing models (CMs) and theoretical model (TM)

\begin{tabular}{|c|c|c|c|c|c|c|c|}
\hline No & Indices & $\begin{array}{l}\text { Name of } \\
\text { index }\end{array}$ & Threshold & Source & $\mathbf{T M}$ & $\mathrm{CM}_{1}$ & $\mathrm{CM}_{2}$ \\
\hline \multirow[t]{2}{*}{1} & Absolute fit & GFI & $>0.90$ & Schumacker and & & & \\
\hline & & & & Lomax (2004) & 0.931 & 0.931 & 0.931 \\
\hline \multirow[t]{7}{*}{2} & Incremental fit & AGFI & $>0.90$ & Schumacker and & & & \\
\hline & & & & Lomax (2004) & 0.853 & 0.858 & 0.852 \\
\hline & & CFI & $>0.90$ & Bentler (1990) & 0042 & 0043 & 0043 \\
\hline & & TLI & $>0.90$ & Bentler and Bonett & & & \\
\hline & & & & $(1980)$ & 0.902 & 0.907 & 0.901 \\
\hline & & NFI & $>0.90$ & $\begin{array}{l}\text { Bentler and Bonett } \\
\text { (1980); Schumacker }\end{array}$ & & & \\
\hline & & & & and Lomax (2004) & 0.921 & 0.921 & 0.921 \\
\hline \multirow[t]{2}{*}{3} & Parsimonious fit & Chi- & $<5$ & Kline (2011); & & & \\
\hline & & square/ $d f$ & & $\begin{array}{l}\text { Schumacker and } \\
\text { Lomax (2004) }\end{array}$ & 3.34 & 3.20 & 3.35 \\
\hline \multirow[t]{2}{*}{4} & $\begin{array}{l}\text { Adjustment of } \\
\text { Improvements }\end{array}$ & AIC & $\begin{array}{l}\text { The smaller } \\
\text { is better }\end{array}$ & $\begin{array}{l}\text { Schumacker and } \\
\text { Lomax (2004) }\end{array}$ & & & \\
\hline & & & & & 2602.74 & 2601.09 & 2602.96 \\
\hline
\end{tabular}

Notes: GFI $=$ Goodness of Fit Index, AGFI $=$ Adjusted Goodness of Fit, CFI $=$ Comparative Fit Index, TLI $=$ Tucker Lewis Index, NFI = Normed Fit Index, AIC = Akaike's Information Criterion. 
Our finding complemented the study by Yazdanpanah et al. (2014), which implied that farmers' intention to conserve water was determined by their perceived behavioral control. Ultimately, being more aware of the value of water conservation influences residents' self-efficacy to perform water conservation efforts more effectively. The study suggests that developing programs to foster residents' awareness of the significance of conserving water is promising to strengthen their willingness to perform water conservation activities in their villages.

\section{Conclusions}

The study concludes that residents perceived behavioral control primarily influences residents' intention and behavior in performing water conservation behaviors in Sanca and Cibeusi village. However, the degree to which attitude toward behavior and subjective norm affect residents' intention remains undetermined. The study contributes to the behavioral models of water conservation initiatives based on the theory of planned behavior (TPB), particularly within the upstream area where the water is abundant. The findings generally confirm the robustness of TPB tenets and serve as additional evidence regarding relations and effects of determinants. First, the existing literature demonstrates that residents' intentions and behavior are more robust when those subjective norms, attitudes, and perceived behavioral control are in a more favorable situation. Interestingly, our findings showed that their perceived behavioral control directly and significantly influenced residents' intentions and behavior. This may be why scholars consider that the exposure of negative impacts of natural resource degradation may trigger residents' attitudes and create the social pressure of conserving natural resources. The less water shortage problems exposure in Sanca and Cibeusi village may lead to the importance of water conservation actions being overlooked. Therefore, we recommend that the specific context in which the research is performed should be considered when assessing residents' intention and behavior toward water conservation initiatives. Second, we found that attitude toward water conservation directly, positively, and significantly affected perceived behavioral control. Indeed, scholars concurred that the attitudes represent the personal evaluation of performing particular behavior. Nevertheless, the current study offers insight that residents' attitudes are not the only attribution of favorable personal evaluation to a specific behavior, but it also impacts their perceived behavioral control.

\section{Acknowledgments}

The authors thank Cibeusi and Sanca villages officials for their permission and support of the research. We also appreciate the reviewers for their valuable comments on the manuscript.

\section{References}

Ahmad, S., Zulkurnain, N., and Khairushalimi, F. 2016. Assessing the Validity and Reliability of a Measurement Model in Structural Equation Modeling (SEM). British Journal of Mathematics and Computer Science 15(3): 1-8. DOI: 10.9734/bjmcs/2016/25183

Ajzen, I. 1991. The Theory of Planned Behavior. Organizational Behavior and Human Decision Processes 50: 179-211. DOI: 10.1016/0749-5978(91)90020-t

Ajzen, I. 2002. Constructing a TPB Questionnaire: Conceptual and Methodological Considerations. https://people.umass.edu/aizen/pdf/tpb.measurement.pdf 
Armitage, C. J., and Conner, M. 2001. Efficacy of the Theory of Planned Behaviour: A MetaAnalytic Review. British Journal of Social Psychology 40(4): 471-499. DOI: 10.1348/014466601164939

Bagozzi, R. P., and Yi, Y. 1988. On the Evaluation of Structural Equation Models. Journal of the Academy of Marketing Science 16(1): 74-94. DOI: 10.1007/bf02723327

Bentler, P. M., and Bonett, D. G. 1980. Significance Tests and Goodness of Fit in the Analysis of Covariance Structures. Psychological Bulletin 88(3): 588-606. DOI: 10.1037/00332909.88.3.588

Bentler, M. P. 1990. Comparative Fit Indexes in Structural Models. In Psychological Bulletin 107. DOI: $10.1037 / 0033-2909.107 .2 .238$

Booij, M. J., Schipper, T. C., and Marhaento, H. 2019. Attributing Changes in Streamflow to Land Use and Climate Change for 472 Catchments in Australia and the United States. Water 11(5): 1059. DOI: $10.3390 /$ w1 1051059

BPS Kabupaten Subang. 2019. Kecamatan Ciater Dalam Angka 2019. https://subangkab.bps.go.id/publication/2019/09/26/f53a8ac114b8ab97149b2f2c/kecamata n-ciater-dalam-angka-2019

Chaudhary, A. K., Warner, L., Lamm, A., Israel, G., Rumble, J., and Cantrell, R. 2017. Using the Theory of Planned Behavior to Encourage Water Conservation among Extension Clients. Journal of Agricultural Education 58(3): 185-202. DOI: 10.5032/jae.2017.03185

Chien, G. C. L., Yen, I. Y., and Hoang, P. Q. 2012. Combination of Theory of Planned Behavior and Motivation: An Exploratory Study of Potential Beach-based Resorts in Vietnam. Asia Pacific Journal of Tourism Research 17(5): 489-508. DOI: 10.1080/10941665.2011.627352

Christopher Westland, J. 2010. Lower Bounds on Sample Size in Structural Equation Modeling. Electronic Commerce Research and Applications 9(6): 476-487. DOI: 10.1016/j.elerap.2010.07.003

Di Matteo, L., Dragoni, W., Piacentini, S. M., and Maccari, D. 2017. Climate Change, Water Supply, and Environmental Problems of Headwaters: The Paradigmatic Case of the Tiber, Savio and Marecchia Rivers (Central Italy). Science of the Total Environment 598: 733-748. DOI: $10.1016 / j . s c i t o t e n v .2017 .04 .153$

Dinar, A., Tieu, A., and Huynh, H. 2019. Water Scarcity Impacts on Global Food Production. Global Food Security 23: 212-226. DOI: 10.1016/j.gfs.2019.07.007

Etikan, I., Musa, S. A., and Alkassim, R. S. 2016. Comparison of Convenience Sampling and Purposive Sampling. American Journal of Theoretical and Applied Statistics 5(1): 1. DOI: 10.11648/j.ajtas.20160501.11

Fitriyana, E. N., Supratman, O., and Mardiani, M. 2020. Sediment Control Analysis Due to Erosion and Sediment in Cipunagara Watershed, Indonesia, Using SWAT Model. IOP Conference Series: Materials Science and Engineering 830(2): 022029. DOI: 10.1088/1757899x/830/2/022029

Floress, K., García de Jalón, S., Church, S. P., Babin, N., Ulrich-Schad, J. D., and Prokopy, L. S. 2017. Toward A Theory of Farmer Conservation Attitudes: Dual Interests and Willingness to Take Action to Protect Water Quality. Journal of Environmental Psychology 53: 73-80. DOI: $10.1016 /$ j.jenvp.2017.06.009

Fuchs, C., and Diamantopoulos, A. 2009. Using Single-Item Measures for Construct Measurement in Management Research: Conceptual Issues and Application Guidelines. Die Betriebswirtschaft 69(2): 195-211. DOI: 10.1021/ja01488a024 
Guo, S., and Hussey, D. L. 2004. Nonprobability Sampling in Social Work Research. Journal of Social Service Research 30(3): 1-18. DOI: 10.1300/J079v30n03_01

Hair, J. F., Anderson, R. E., Tatham, R. L., and Black, W. C. 1998. Multivariate Data Analysis with Readings (5nd ed.). In Prentice-Hall, Upper Saddle River.

Iacobucci, D. 2009. Everything You Always Wanted to Know About SEM (Structural Equations Modeling) but Were Afraid to Ask. Journal of Consumer Psychology 19(4): 673-680. DOI: 10.1016/j.jcps.2009.09.002

Javlec. 2021. Javlec Indonesia Sosialisasikan Program Desa Ramah Air Hujan (DeRAH). Javlec. https://javlec.org/javlec-indonesia-sosialisasikan-program-desa-ramah-air-hujan-derah/

Javlec. 2019. Laporan Akhir Konservasi di Sub DAS Cipunagara Kabupaten Subang tahun 2019. Yayasan Javlec Indonesia. Yogyakarta.

Juwana, I., and Nugroho, D. P. 2020. Calculation of Pollutant Load in Cipunagara River: Livestock Sector. Journal of the Civil Engineering Forum 6(1): 145. DOI: 10.22146/jcef.52675

Kline, R. B. 2011. Principles and Practice of Structural Equation Modeling. In Guilford Publication. DOI: 10.1017/cbo9781107415324.004

Křeček, J., and Haigh, M. 2019. Land Use Policy in Headwater Catchments. Land Use Policy 80: 410-414. DOI: 10.1016/j.landusepol.2018.03.043

Kumar, P., Avtar, R., Dasgupta, R., Johnson, B. A., Mukherjee, A., Ahsan, Md. N., Nguyen, D. C. H., Nguyen, H. Q., Shaw, R., and Mishra, B. K. 2020. Socio-Hydrology: A Key Approach for Adaptation to Water Scarcity and Achieving Human Well-Being in Large Riverine Islands. Progress in Disaster Science 8: 100134. DOI: 10.1016/j.pdisas.2020.100134

Lee, J., Perera, D., Glickman, T., and Taing, L. 2020. Water-Related Disasters and Their Health Impacts: A Global Review. Progress in Disaster Science 8: 100123. DOI: 10.1016/j.pdisas.2020.100123

Li, M., Peng, C., Zhang, K., Xu, L., Wang, J., Yang, Y., Li, P., Liu, Z., and He, N. 2021. Headwater Stream Ecosystem: An Important Source of Greenhouse Gases to the Atmosphere. Water Research 190: 116738. DOI: 10.1016/j.watres.2020.116738

Maleksaeidi, H., and Keshavarz, M. 2019. What Influences Farmers' Intentions to Conserve OnFarm Biodiversity? An Application of the Theory of Planned Behavior in Fars Province, Iran. Global Ecology and Conservation 20: e00698. DOI: 10.1016/j.gecco.2019.e00698

Marhaento, H., Booij, M. J., and Hoekstra, A. Y. 2018. Hydrological Response to Future LandUse Change and Climate Change in a Tropical Catchment. Hydrological Sciences Journal 63(9): 1368-1385. DOI: 10.1080/02626667.2018.1511054

Memon, M. A., Ting, H., Cheah, J. H., Thurasamy, R., Chuah, F., and Cham, T. H. 2020. Sample Size for Survey Research: Review and Recommendations. Journal of Applied Structural Equation Modeling 4(2): 1-20. DOI: 10.47263/jasem.4(2)01

Mihanyar, P., Rahman, S. A., and Aminudin, N. 2016. Investigating the Effect of National Park Sustainability on National Park Behavioral Intention: Kinabalu National Park. Procedia Economics and Finance 37: 284-291. DOI: 10.1016/s2212-5671(16)30126-5

Moragoda, N., and Cohen, S. 2020. Climate-Induced Trends in Global Riverine Water Discharge and Suspended Sediment Dynamics in the 21st Century. Global and Planetary Change 191: 103199. DOI: 10.1016/j.gloplacha.2020.103199

Nugroho, P., Marsono, D., Sudira, P., and Suryatmojo, H. 2013. Impact of Land-use Changes on Water Balance. Procedia Environmental Sciences 17: 256-262. DOI: 10.1016/j.proenv.2013.02.036 
Nur, W. H., Hendrizan, M., Nurhidayati, A. U., and Ismayanto, A. F. 2020. Estuary Changes of Cipunagara and Cimanuk River Using Landsat Imagery Spatial Analysis. Bulletin of the Marine Geology 35(2): 65-78. DOI: 10.32693/bomg.35.2.2020.690

Pemerintah Daerah Jawa Barat. 2019. Rilis Launching Penanaman Pohon Daerah Konervasi Desa Cibeusi Ciater - Website Resmi Pemerintah Provinsi Jawa Barat. https://jabarprov.go.id/index.php/news/31414/Rilis_Launching_Penanaman_Pohon_Daera h_Konervasi_Desa_Cibeusi_Ciater

Perren, K., and Yang, L. 2015. Psychosocial and Behavioural Factors Associated with Intention to Save Water Around the Home: A Greek Case Study. Procedia Engineering 119(1): 14471454. DOI: 10.1016/j.proeng.2015.08.1005

Rivera, J. D. 2019. When Attaining the Best Sample is Out of Reach: Nonprobability Alternatives When Engaging in Public Administration Research. Journal of Public Affairs Education 25(3): 314-342. DOI: 10.1080/15236803.2018.1429821

Rosseel, Y. 2012. Lavaan: An R Package for Structural Equation. Journal of Statistical Software. DOI: $10.18637 /$ jss.v048.i02

Russell, S. V., and Knoeri, C. 2020. Exploring the Psychosocial and Behavioural Determinants of Household Water Conservation and Intention. International Journal of Water Resources Development 36(6): 940-955. DOI: 10.1080/07900627.2019.1638230

Savari, M., and Gharechaee, H. 2020. Application of the Extended Theory of Planned Behavior to Predict Iranian Farmers' Intention for Safe Use of Chemical Fertilizers. Journal of Cleaner Production 263: 121512. DOI: 10.1016/j.jclepro.2020.121512

Schumacker and Lomax R. G., R. E. 2004. A Beginner's Guide to Structural Equation Modeling. In Technometrics. DOI: 10.1198/tech.2005.s328

Shahangian, S. A., Tabesh, M., and Yazdanpanah, M. 2021. How Can Socio-Psychological Factors be Related to Water-Efficiency Intention and Behaviors among Iranian Residential Water Consumers? Journal of Environmental Management 288: 112466. DOI: 10.1016/j.jenvman.2021.112466

Soper, D. 2021. Free A-priori Sample Size Calculator for Structural Equation Models - Free Statistics Calculators. Retrieved November 16 2021, from https://www.danielsoper.com/statcalc/calculator.aspx?id=89

Suryatmojo, H. 2015. Rainfall-runoff Investigation of Pine Forest Plantation in the Upstream Area of Gajah Mungkur Reservoir. Procedia Environmental Sciences 28: 307-314. DOI: 10.1016/j.proenv.2015.07.039

Taber, K. S. 2018. The Use of Cronbach's Alpha When Developing and Reporting Research Instruments in Science Education. Research in Science Education 48(6): 1273-1296. DOI: 10.1007/s11165-016-9602-2

Taherzadeh, O., Bithell, M., and Richards, K. 2021. Water, Energy and Land Insecurity in Global Supply Chains. Global Environmental Change 67: 102158. DOI: 10.1016/j.gloenvcha.2020.102158

Tama, R. A. Z., Ying, L., Yu, M., Hoque, M. M., Adnan, K. M., and Sarker, S. A. 2021. Assessing Farmers' Intention Towards Conservation Agriculture by Using the Extended Theory of Planned Behavior. Journal of Environmental Management 280: 111654. DOI: 10.1016/j.jenvman.2020.111654 
Tarka, P. 2017. An Overview of Structural Equation Modeling: Its Beginnings, Historical Development, Usefulness and Controversies in the Social Sciences. Quality and Quantity 52: 313-354. DOI: 10.1007/s11135-017-0469-8

Team, Rs. 2015. RStudio: Integrated Development for R. In [Online] RStudio, Inc., Boston, MA http://www.rstudio.com and https://doi.org/https://www.nrel.gov/docs/fy16osti/65298.pdf

Valentin, C., Agus, F., Alamban, R., Boosaner, A., Bricquet, J. P., Chaplot, V., de Guzman, T., de Rouw, A., Janeau, J. L., Orange, D., Phachomphonh, K., do Duy Phai, Podwojewski, P., Ribolzi, O., Silvera, N., Subagyono, K., Thiébaux, J. P., Tran Duc Toan, and Vadari, T. 2008. Runoff and Sediment Losses from 27 Upland Catchments in Southeast Asia: Impact of Rapid Land Use Changes and Conservation Practices. Agriculture, Ecosystems and Environment 128(4): 225-238. DOI: 10.1016/j.agee.2008.06.004

Valizadeh, N., Bijani, M., Karimi, H., Naeimi, A., Hayati, D., and Azadi, H. 2020. The Effects of Farmers' Place Attachment and Identity on Water Conservation Moral Norms and Intention. Water Research 185: 116131. DOI: 10.1016/j.watres.2020.116131

Warner, L. A. 2021. Who Conserves and Who Approves? Predicting Water Conservation Intentions in Urban Landscapes with Referent Groups Beyond the Traditional 'Important Others.' Urban Forestry and Urban Greening 60: 127070. DOI: 10.1016/j.ufug.2021.127070

Warner, L. A., Lamm, A. J., and Kumar Chaudhary, A. 2018. Florida Residents' Perceived Role in Protecting Water Quantity and Quality Through Landscape Practices. Landscape and Urban Planning 171: 1-6. DOI: 10.1016/j.landurbplan.2017.11.007

Weston, R., and Gore, P. A. 2006. A Brief Guide to Structural Equation Modeling. The Counseling Psychologist 34(5): 719-751. DOI: 10.1177/0011000006286345

Yazdanpanah, M., Forouzani, M., Abdeshahi, A., and Jafari, A. 2016. Investigating the Effect of Moral Norm and Self-Identity on the Intention Toward Water Conservation among Iranian Young Adults. Water Policy 18(1): 73-90. DOI: 10.2166/wp.2015.031

Yazdanpanah, M., Hayati, D., Hochrainer-Stigler, S., and Zamani, G. H. 2014. Understanding Farmers' Intention and Behavior Regarding Water Conservation in the Middle-East and North Africa: A case study in Iran. Journal of Environmental Management 135: 63-72. DOI: 10.1016/j.jenvman.2014.01.016

Zheng, W., Wang, S., Sprenger, M., Liu, B., and Cao, J. 2019. Response of Soil Water Movement and Groundwater Recharge to Extreme Precipitation in a Headwater Catchment in the North China Plain. Journal of Hydrology 576: 466-477. DOI: 10.1016/j.jhydrol.2019.06.071 